\title{
PERUBAHAN PERILAKU MEMBANGUN RUMAH PASCA GEMPA 2006 DI YOGYAKARTA - STUDI KASUS PENGEMBANGAN 18 RUMAH BANTUAN JRF DI KABUPATEN BANTUL
}

\author{
Johanita Anggia Rini ${ }^{1}$, Sugeng Triyadi ${ }^{2}$, Tri Yuwono ${ }^{3}$ \\ ${ }^{1}$ Program Studi Arsitektur Universitas Islam Indonesia \\ ${ }^{2}$ Program Studi Arsitektur Institut Teknologi Bandung \\ ${ }^{3}$ Program Studi Arsitektur Institut Teknologi Bandung \\ johanita@uii.ac.id
}

\begin{abstract}
ABSTRAK. Masyarakat korban gempa 2006 di Yogyakarta menerima berbagai bantuan dalam proses membangun kembali rumahnya yang hancur, antara lain dengan bantuan Java Reconstruction Fund (JRF). Bantuan ini tidak hanya berbentuk dana untuk membangun rumah, namun juga pembelajaran membangun dengan prinsip tahan gempa, dan pengawasan selama proses pembangunan. Dengan cara pembelajaran adaptif ini, diharapkan pemilik rumah dapat mengadaptasi cara membangun rumah yang tahan gempa untuk seterusnya. Bertahun-tahun kemudian, pemilik rumah mulai mengembangkan rumahnya secara mandiri, tanpa bantuan dan pengawasan dari pihak luar. Penelitian ini mengkaji apakah perilaku membangun rumah dengan prinsip tahan gempa sudah dipraktekkan secara lestari oleh pemilik rumah, dengan cara meninjau fisik bangunan tambahan yang dibangun secara mandiri. Lebih lanjut, penelitian juga melihat sejauh mana keberhasilan pembelajaran adaptif yang diterima oleh pemilik rumah dilihat dari kacamata tahapan perubahan perilaku membangun. Hasil penelitian dapat digunakan untuk menggambarkan kerentanan fisik rumah yang menjadi obyek studi mengingat potensi gempa masih selalu mengancam Kabupaten Bantul, dan menduga pengaruh proses pembelajaran adaptif terhadap perubahan perilaku membangun.
\end{abstract}

Kata kunci: prinsip tahan gempa, pembelajaran adaptif, perubahan perilaku

ABSTRACT. The victims of the 2006 earthquake in Yogyakarta have received assistance in the reconstruction of their destroyed houses. One of them is Java Reconstruction Fund (JRF) program. This assistance came not only in the form of funds to rebuild houses, but also learning to build a house with earthquake resistant principles, and supervision during the development process. This system is referred to as adaptive learning. Homeowners are expected to be able to adapt the new way to build earthquake-resistant houses forever. Years later, homeowners began to develop their home independently, without help and supervision from outside. This study has examined whether the behavior to build earthquake-resistant houses have already been practiced in a sustainable manner by the homeowners, by means of reviewing the physical of additional buildings that has been constructed independently later. Furthermore, the study also looked at the level of adaptive learning received by the homeowner as perceived stages of behavior change. Results of the study can be used to describe the physical vulnerability of houses that became the object of study given the potential for an earthquake in Bantul is always threatening, and suspect the influence of the adaptive learning process to behavior change.

Keywords: earthquake resistant principles, adaptive learning, behavior change

\section{PENDAHULUAN}

Kegiatan pembangunan kembali rumah yang hancur pasca gempa di Yogyakarta secara resmi dimulai tanggal 3 Juli 2006 di bawah kendali Tim Koordinasi Rehabilitasi dan Rekonstruksi Wilayah Pasca Bencana Gempa Bumi di Provinsi DIY dan Jawa Tengah [1].

Terdapat berbagai program bantuan yang diterima pemilik rumah untuk membangun kembali rumahnya, salah satunya adalah bantuan dari Java Reconstruction Fund (JRF). Bantuan JRF adalah bantuan yang dikelola oleh World Bank sebagai amilnya. Bantuan ini sendiri direalisasikan di Yogyakarta pasca gempa 2006 melalui program REKOMPAK JRF yang bekerjasama dengan Ciptakarya. Berdasarkan wawancara yang dilakukan dengan penerima bantuan, dana yang diberikan untuk rekonstruksi satu rumah tahan gempa sebesar dua puluh juta rupiah yang turun dalam tiga tahap untuk membangun rumah sebesar kurang lebih $27 \mathrm{~m}^{2}$. 


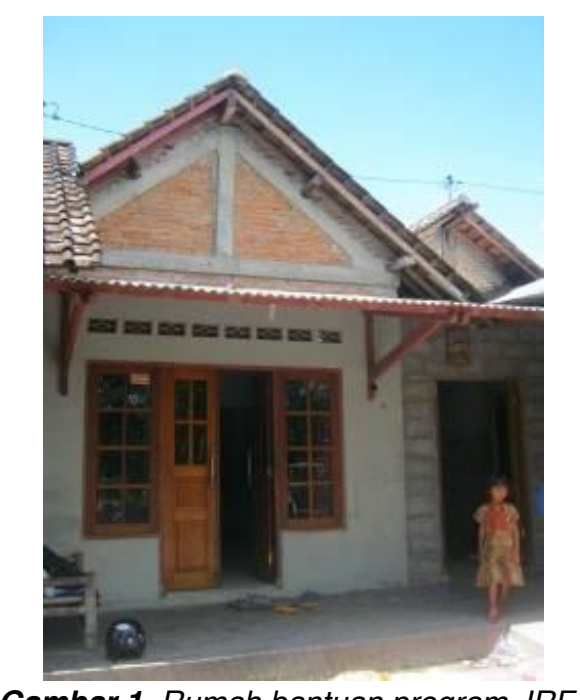

Gambar 1. Rumah bantuan program JRF.

Dibandingkan program bantuan dari sumber lain, program bantuan JRF memiliki ciri khas yang kuat yaitu desain fisik rumah yang sangat ketat mengikuti prinsip tahan gempa, serta adanya berbagai usaha pembelajaran membangun dengan prinsip tahan gempa terhadap pemilik rumah maupun tukang yang terlibat dalam pembangunan.

Dalam pelaksanaan pembangunan, penerima bantuan dibagi menjadi kelompok kecil dengan organisasi seperti ketua, sekretaris, dan bendahara. Kelompok mendapatkan sosialisasi dari fasilitator, termasuk mengenai prinsip rumah tahan gempa. Tiap pemilik rumah wajib terlibat dalam proses pembangunan rumahnya, minimal dalam tahap desain dan pengawasan terhadap tukang sepanjang proses pembangunan. Pemilik rumah mendapatkan gambar atau panduan membangun dengan prinsip tahan gempa yang harus diikuti dalam membangun. Di beberapa tempat juga diadakan pelatihan membangun meskipun tidak semua kelompok mendapat program ini.

Selama proses pembangunan, fasilitator teknis melakukan pengawasan untuk memastikan cara membangun dan material yang dipakai sudah memenuhi standar tahan gempa. Apabila terjadi kesalahan di lapangan, maka harus dilakukan koreksi dulu atau bantuan tahap selanjutnya tidak akan bisa turun. Pemilik rumah yang dinilai sudah berhasil membangun dengan baik diberi penghargaan berupa 'Serifikat Rumah Tahan Gempa'. Beberapa juga mendapatkan plakat bertuliskan 'Rumah Tahan Gempa' yang ditempel di muka rumah.

Pada tahun 2012, terpantau sudah cukup banyak rumah penerima bantuan JRF yang dikembangkan secara mandiri oleh pemiliknya, karena kebutuhan penambahan ruang maupun alasan lain. Penambahan bangunan baru tersebut menempel pada bagian rumah yang merupakan bantuan JRF terdahulu. Pengembangan rumah ini dilakukan secara mandiri oleh pemilik rumah, tanpa bantuan dana, panduan, maupun pengawasan dari pihak luar. Fenomena pengembangan rumah ini perlu diteliti, apakah perilaku membangun rumah dengan prinsip tahan gempa yang sudah pernah diajarkan masih dipraktekkan oleh pemilik rumah. Dengan demikian dapat dilihat sejauh mana keberhasilan pembelajaran adaptif yang diterima oleh pemilik rumah.

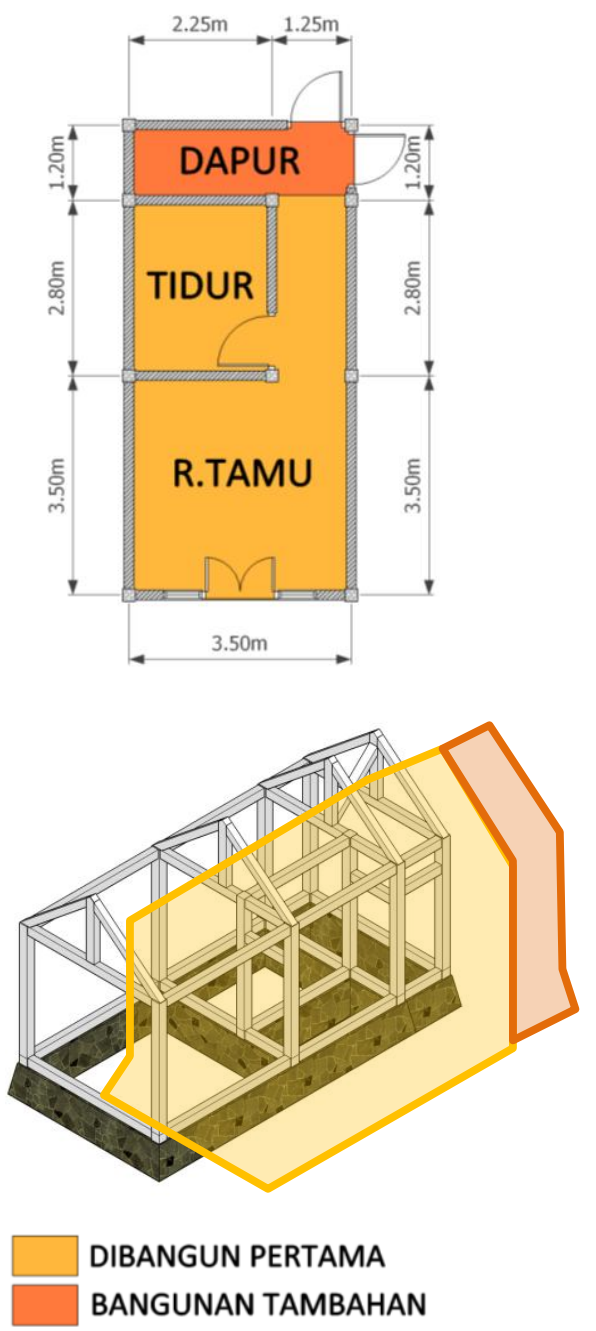

Gambar 2. Denah penambahan ruang secara mandiri pada rumah bantuan JRF.

\section{METODE}

Penelitian ini masuk ke dalam jenis penelitian eksploratif dengan metode observasi lapangan, wawancara mendalam, studi literatur, dan analisis deskriptif. Sebagai obyek studi kasus, diambil 18 rumah penerima bantuan JRF dengan struktur rangka beton bertulang satu lantai, yang 
telah dikembangkan secara mandiri di kemudian hari oleh pemiliknya. Ke 18 rumah tersebut berlokasi di Kabupaten Bantul yang merupakan wilayah paling parah terkena dampak gempa, tepatnya di kelurahan Banguntapan, Potorono, dan Jambidan.

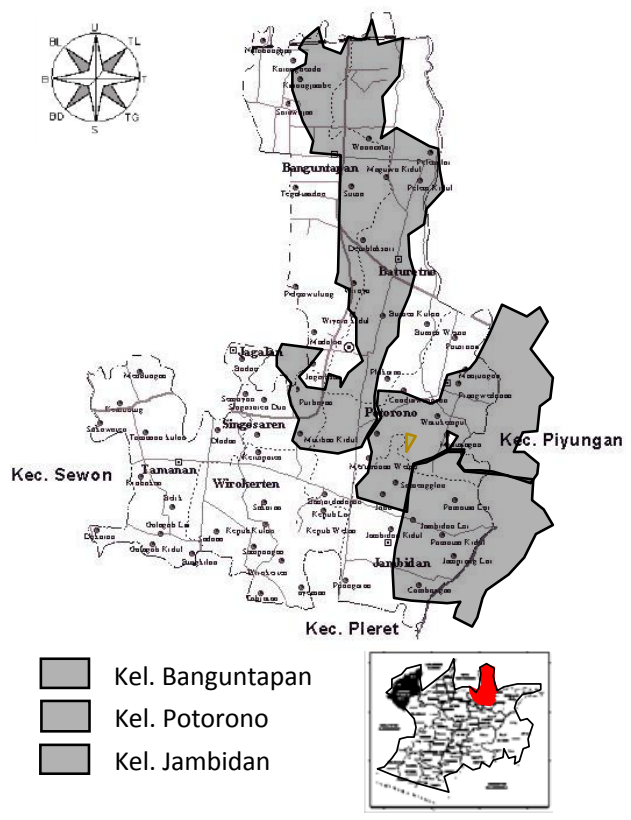

Gambar 3. Lokasi penelitian di Kecamatan Banguntapan.

Sumber : APPL, 2012 [2] dan LP3Y, 2007[3]

Dilakukan wawancara dengan pemilik rumah, serta dilakukan pengamatan langsung terhadap kondisi fisik rumah untuk .mengetahui prosentase penerapan prinsip tahan gempa pada setiap rumah. Analisis deskriptif dilakukan untuk mengetahui penerapan prinsip-prinsip pembelajaran adaptif dan tahapan perubahan perilaku dalam pembelajaran adaptif dari berbagai literatur. Selanjutnya dilihat hubungan antara pelaksanaan pembelajaran adaptif dengan tingkat penerapan prinsip tahan gempa.

\section{PEMBELAJARAN ADAPTIF}

Pembelajaran mengenai prinsip tahan gempa yang dilakukan oleh program bantuan JRF kepada pemilik rumah dapat dimasukkan dalam model pembelajaran adaptif. Rumah tahan gempa adalah sebuah teknologi baru bagi masyarakat. Penerapannya membutuhkan cara berpikir yang baru, serta penyesuaian terhadap kondisi lokal.

Model pembelajaran adaptif banyak digunakan dalam proses rekonstruksi pasca bencana yang bertujuan menanamkan kebiasaan membangun dengan prinsip baru, dan melibatkan pemilik sebagai aktor utamanya. Menurut Bond dan Hulme dalam Leersum dan Arora [4], model pembelajaran adaptif lebih baik daripada model blue prints dalam membentuk pembangunan sebagai sebuah proses. Apabila sebuah program bantuan ingin tujuannya tercapai dan apa yang diajarkan terus dipakai secara lestari, maka program itu idealnya memenuhi prinsip-prinsip pembelajaran adaptif. Prinsip-prinsip pembelajaran adaptif menurut Bond dan Hulme dalam Leersum dan Arora [4] adalah:

1) Pelaksanaan yang bertahap dan fleksibel. Dalam proses rekonstruksi pasca gempa prinsip ini diimplementasikan antara lain dengan pemberian bantuan dana dan pembangunan fisik yang bertahap, diadakannya program yang berbeda-beda untuk tiap grup sasaran, tidak menetapkan satu jenis konstruksi saja, serta penyesuaian ukuran dan desain rumah dengan lahan yang dipunyai pemilik rumah.

2) Belajar dari pengalaman. Terdapat dua jenis pembelajaran yaitu pembelajaran secara sistematis dan institusional, dan belajar dari kearifan dan lingkungan lokal.

Pembelajaran secara sistematis dan institusional dapat dilakukan dengan pelatihan formal, misalnya sosialisasi struktur tahan gempa, pelatihan pemilik rumah dan tukang, mempekerjakan tukang yang telah dilatih, pemberian bahan seperti pictorial step by step membangun rumah, dan pendampingan dan pengawasan lapangan. Pembelajaran dapat juga dilakukan secara informal, misalnya dengan adanya observasi mandiri oleh pemilik, interaksi, personal reasoning, atau adanya budaya pemagangan tukang. Belajar dari kearifan dan lingkungan lokal dilakukan antara lain dengan cara mengetahui teknik konstruksi yang dipahami masyarakat, penyesuaian dengan kondisi finansial masyarakat, penyesuaian dengan ketersediaan material, dan penyesuaian persepsi sosio-kultural.

3) Partisipasi penerima bantuan, antara lain dapat dilihat dengan cara mengukur berapa banyak keputusan yang dibuat oleh pemilik rumah? Seberapa banyak pemilik rumah terlibat mengerjakan?

4) Dukungan institusional, antara lain dengan cara penyerahan keputusan ke level lokal, memanfaatkan institusi yang sudah ada, dan tidak melangkahi institusi lokal. 
5) Manajemen program, yaitu dengan adanya pendampingan teknis jangka pendek yang berfokus pada penyediaan produk yaitu rumah bantuan, serta pendampingan teknis jangka panjang yang berfokus pada pembangunan lanjutan dan menghindari adanya ketergantungan.

\section{PERUBAHAN PERILAKU MEMBANGUN}

Dengan dilakukannya pembelajaran adaptif, diharapkan pemilik rumah meninggalkan kebiasaan membangun konvensional dan beralih ke cara membangun yang sesuai prinsip tahan gempa. Perubahan perilaku membangun ini tentu tidak dapat terjadi secara serta-merta, melainkan secara bertahap.

Terdapat poin-poin spesifik yang perlu dilakukan dalam setiap tahap agar perilaku pemilik rumah dapat berubah sesuai yang diinginkan secara berkelanjutan. Menurut Andreasen [5], terdapat empat tahap dalam perubahan perilaku yaitu tahap pra kontemplasi, tahap kontemplasi, tahap aksi, dan tahap pemeliharaan.

1) Tahap Pra Kontemplasi, bertujuan agar seseorang mengetahui tentang pentingnya perilaku baru yang ditawarkan, misalnya pentingnya membangun dengan prinsip tahan gempa. Dalam tahap ini, pemberi bantuan menyampaikan apa yang penting untuk masyarakat dengan bahasa yang dimengerti dan cara yang lebih menarik perhatian sasaran.

2) Tahap Kontemplasi, bertujuan agar seseorang memutuskan untuk mengubah perilakunya sesuai yang diinginkan. Pada tahap ini, akan terjadi kompetisi antara perilaku yang disosialisaikan dengan alternatif perilaku lain. Misalnya perilaku membangun dengan prinsip tahan gempa berkompetisi dengan perilaku membangun tanpa prinsip tahan gempa. Pemilik rumah akan berperilaku sesuai keyakinannya, yaitu keyakinan akan konsekuensi positif (benefit) dan negatif (cost) dari suatu perilaku. Dalam membangun dengan prinsip tahan gempa, konsekuensi positif (benefit) misalnya adalah keselamatan keluarga dalam bencana gempa. Konsekuensi negatif (cost) nya adalah biaya pembangunan yang mahal, waktu membangun lebih lama, dan teknis pembangunan lebih sulit.

Untuk meningkatkan perubahan perilaku, maka perilaku yang diajarkan harus memiliki rasio benefit terhadap cost yang lebih besar dari alternatif perilaku yang lain. Keyakinan mengenai apa yang diharapkan orang lain juga mendorong sesorang untuk berperilaku. Karena itu, peran pihak lain bisa jadi signifikan sebagai sumber informasi maupun sumber tekanan sosial.

Terakhir, perubahan perilaku di tahap ini juga dipengaruhi oleh keyakinan seseorang akan kemampuan dirinya melakukan perilaku tersebut. Bisa jadi pemilik rumah menginginkan membangun dengan prinsip tahan gempa, namun merasa dirinya tidak mampu melakukannya. Pemberi bantuan bertugas untuk menumbuhkan keyakinan tersebut.

3) Tahap Aksi, bertujuan agar seseorang memiliki keyakinan bahwa suatu perilaku dapat benar-benar dilaksanakan sehingga dia melakukan perilaku tersebut. Keyakinan akan seberapa mudah atau sulitnya pelaksanaan perilaku (perceived behavioural control) dipengaruhi oleh Internal Efficacy (apakah dia merasa punya skill dan knowledge yang cukup untuk melaksanakan perilaku) dan External Efficacy (Apakah lingkungan mendukung perilaku tersebut). Jika perilaku yang diinginkan tersebut gagal dilaksanakan, dapat dilihat siapa yang disalahkan untuk memilih tindak lanjutnya.

4) Tahap Pemeliharaan, bertujuan untuk memberikan pembenaran atas perilaku baru yang telah berhasil dilakukan, dengan cara mengadakan kegiatan lanjutan untuk mengingatkan manfaat dari perilaku tersebut, memberikan material untuk pengingat, atau pemberian penghargaan.

\section{PEMBANGUNAN RUMAH TINGGAL DENGAN PRINSIP TAHAN GEMPA}

Pedoman pembangunan rumah tahan gempa yang disosialisasikan kepada penerima bantuan JRF mengacu pada panduan Tedy Boen dan Dirjen Cipta Karya. Menurut Boen dkk [6,7,8,9] dan Dirjen Cipta Karya [10], prinsip tahan gempa terdiri dari 9 syarat utama:

1) Pemilihan jenis tanah dan kestabilan lereng.

2) Konfigurasi masa dan denah

3) Desain bukaan

4) Berat bangunan

5) Kekakuan

6) Kekuatan

7) Dimensi komponen struktur

8) Kualitas material struktur

9) Proses konstruksi struktur utama 


\section{HASIL DAN PEMBAHASAN}

\section{Penerapan prinsip tahan gempa pada rumah bantuan yang telah dikembangkan secara mandiri}

Untuk melihat bagaimana penerapan prinsip tahan gempa oleh penerima bantuan JRF, dilakukan penilaian terhadap rumah bantuan JRF baik bagian rumah yang merupakan bantuan maupun bagian rumah yang dikembangkan sendiri oleh pemiliknya. Cara ini digunakan untuk mengetahui tingkat penerapan prinsip tahan gempa yang sebenarnya sesuai kesadaran dan kemampuan pemilik saat mengembangkan rumahnya secara mandiri.

Penilaian mengacu pada prinsip-prinsip tahan gempa dari Teddy Boen dkk. [6,7,8,9] dan Pedoman Pembangunan Bangunan Tahan Gempa Dirjen Cipta Karya [10] yang telah disebutkan sebelumnya. Metode yang digunakan adalah perbandingan jumlah nilai yang diterapkan dari jumlah total nilai yang disyaratkan untuk rumah tahan gempa. Nilainya kemudian dikonversi menjadi prosentase, agar tetap dapat dibandingkan meskipun tidak semua rumah memiliki jumlah total poin yang sama.

Dari hasil penilaian, didapat bahwa ke-18 rumah asli yang merupakan bantuan JRF sudah menerapkan prinsip tahan gempa lebih dari $60 \%$. Bahkan banyak yang penerapannya mencapai lebih dari $90 \%$. Penerapan paling tinggi sebesar 98\% pada rumah nomor 2 dan nomor 14 . Penerapan paling rendah sebesar $78,4 \%$ pada rumah nomor 11.

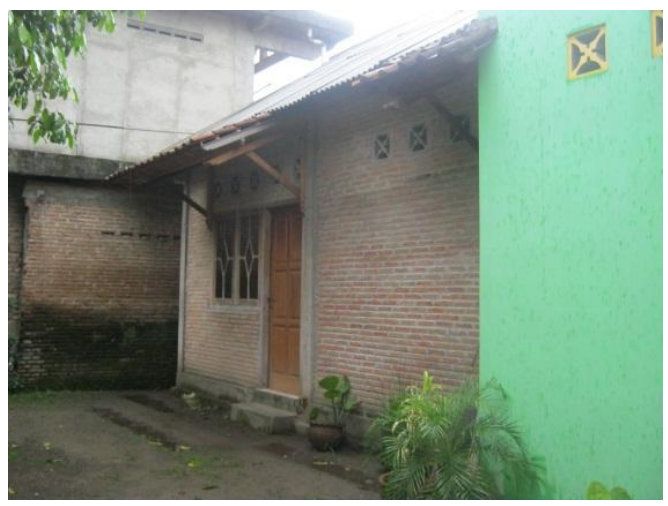

Gambar 4. Rumah bantuan JRF nomor 14.

Hasil yang berbeda didapatkan pada bagian rumah yang dibangun mandiri oleh pemiliknya pasca program bantuan JRF usai. Tingkat penerapan prinsip tahan gempa pada bagian ini cukup rendah. Hanya 5 rumah yang menerapkan prinsip tahan gempa diatas $60 \%$. Penerapan paling tinggi sebesar $87,5 \%$ pada rumah nomor
14 , sedang penerapan paling rendah sebesar $19,1 \%$ pada rumah nomor 7 .

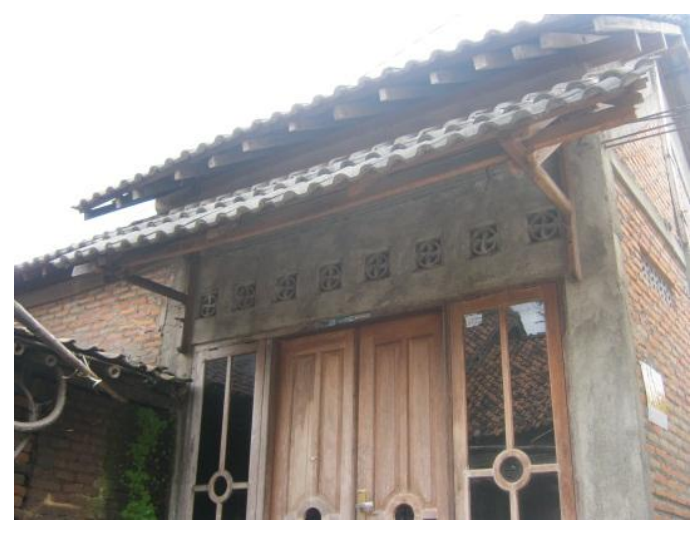

Gambar 5. Rumah bantuan JRF nomor 7.

Perbandingan penerapan prinsip tahan gempa antara bagian rumah asli yang merupakan bantuan JRF dengan bagian yang dibangun mandiri pada setiap rumah dapat dilihat pada grafik berikut.

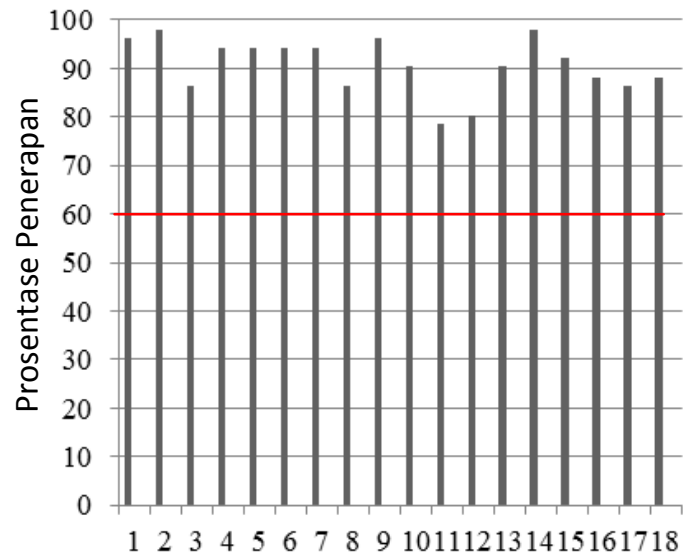

Nomor Rumah

Gambar 6. Prosentase penerapan prinsip tahan gempa pada bagian rumah asli yang dibantu JRF

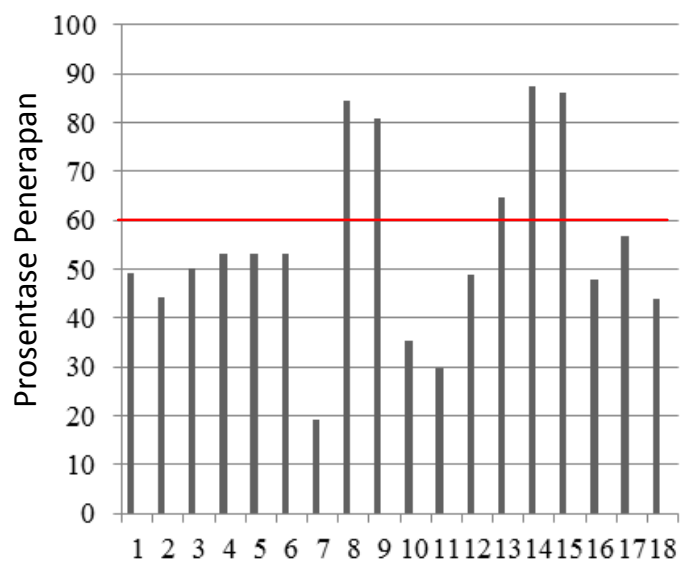

Nomor Rumah

Gambar 7. Prosentase penerapan prinsip tahan gempa pada bagian rumah yang dikembangkan secara mandiri. 
Dari hasil penilaian ini, dapat dilihat bahwa prinsip tahan gempa yang sudah pernah diajarkan sebelumnya belum diterapkan secara lestari ketika pemilik rumah mengembangkan rumahnya sendiri tanpa bantuan dan pengawasan pihak lain.

\section{Penerapan prinsip pembelajaran adaptif dalam program bantuan JRF}

Tingkat keberhasilan pelaksanaannya pembelajaran adaptif membangun dengan prinsip tahan gempa yang diberikan dalam program JRF dianalisa melalui diterapkan atau tidaknya prinsip-prinsip pembelajaran adaptif selama program bantuan berjalan di tahun 20062007. Prinsip yang diamati berdasarkan teori Bond dan Hulme dalam Leersum dan Arora [4] seperti yang telah dibahas sebelumnya.

1) Penerapan yang Bertahap dan Fleksibel Bantuan dana dari program JRF diturunkan secara bertahap, begitu juga dengan pelaksanaan pembangunannya. Namun berdasarkan wawancara, kebanyakan pemilik rumah hanya disediakan satu jenis program pembelajaran saja yaitu sosialisasi prinsip tahan gempa, meskipun ada juga kelompok yang mendapat sosialisasi dan pelatihan membangun.

Ukuran serta denah rumah dapat disesuaikan dengan lahan dan keinginan pemilik dengan persetujuan fasilitator. Namun Jenis konstruksi ditetapkan hanya dengan rangka beton bertulang, sehingga kurang fleksibel jika pemilik rumah menginginkan jenis struktur dan konstruksi lain.

\section{2) Belajar dari Pengalaman}

Dari 18 pemilik rumah yang diwawancara, semuanya sudah pernah mendapatkan sosialisasi membangun dengan prinsip tahan gempa, meski ada yang sosialisasinya rutin dan ada yang tidak. Menurut 17 pemilik rumah, tidak ada program pelatihan tukang, dan JRF tidak mempekerjakan tukang yang telah dilatih.

Sebagai panduan membangun, semua pemilik rumah memiliki gambar atau petunjuk pembangunan dengan prinsip tahan gempa. Pembangunan rumah diawasi langsung oleh fasilitator meskipun ada yang diawasi secara rutin dan ada yang tidak.

Selama proses pembangunan, terjadi interaksi secara informal antar pemilik rumah untuk saling bertukar pengetahuan tentang prinsip tahan gempa. Namun pemilik rumah cenderung tidak terpacu untuk melakukan observasi mandiri, melainkan hanya mengikuti aturan yang sudah diperintahkan secara ketat. Mereka juga tidak memiliki alasan pribadi tertentu dalam membangun rumahnya. Juga tidak ditemukan adanya budaya pemagangan tukang untuk menyalurkan ilmu secara informal.

Bentuk dan desain rumah yang cenderung given dan seragam tidak disesuaikan dengan persepsi sosio-kultural masyarakat mengenai rumah yang bagus. Karena itu, banyak pemilik rumah yang kemudian melakukan pengembangan agar tampilan rumah lebih sesuai dengan seleranya.

Program bantuan juga kurang berusaha memahami kebiasaan lokal terlebih dahulu. Sebelumnya, tidak diselidiki apakah sistem konstruksi yang ditawarkan familiar bagi pemilik rumah. Ketika diwawancara pemilik rumah mengungkapkan bahwa spesifikasi material yang disyaratkan terasa mahal bagi kondisi ekonomi mereka.

\section{3) Partisipasi Penerima Bantuan}

Meskipun sebagian pemilik rumah berpartisipasi mengerjakan rumahnya secara langsung, tidak banyak keputusan struktural yang diambil oleh pemilik rumah. Kondisi ini karena semua aturan membangun sudah ditentukan oleh pemberi bantuan secara ketat. Keputusan merubah desain atau ukuran juga harus sepersetujuan fasilitator.

\section{4) Dukungan Institusional}

Program bantuan JRF telah melibatkan institusi lokal seperti kelurahan dan kecamatan untuk mendata dan mengajukan rumah yang membutuhkan bantuan. Namun yang memutuskan siapa yang berhak menerima bantuan tetap pihak JRF.

\section{5) Manajemen Program}

Selama program bantuan JRF berlangsung, pemilik rumah telah mendapatkan pendampingan teknis jangka pendek untuk membangun rumah tahan gempa sampai rumah selesai dibangun. Namun sesudah program usai, pemilik rumah belum pernah mendapatkan pendampingan teknis jangka panjang secara langsung. Langkah yang dilakukan baru sekedar memberi materi dan tanda pengingat untuk disimpan.

\section{Tahapan Perubahan Perilaku Membangun dengan Prinsip Tahan Gempa}

Perubahan perilaku membangun pemilik rumah yang telah mendapatkan pembelajaran adaptif dari program bantuan JRF dianalisa menurut teori tahap perubahan perilaku dari Andreasen [5]. 


\section{1) Tahap Pra Kontemplasi}

Dari hasil wawancara, dapat disimpulkan bahwa tujuan dari tahap pra kontemplasi telah tercapai, karena 18 pemilik rumah telah merasakan pentingnya memiliki rumah tahan gempa. Aktifitas kunci pada tahap ini adalah pemberian edukasi, dan telah dilakukan dengan bentuk sosialisasi prinsip tahan gempa meskipun di sebagian tempat belum dilakukan secara rutin. Pada satu kasus (rumah nomor 8) edukasi bahkan dilengkapi dengan pelatihan membangun secara praktik.

Pada saat wawancara, seluruh pemilik rumah dapat menunjukkan salinan gambar kerja yang digunakan sebagai panduan membangun. Namun demikian ada pemilik yang tidak memiliki kemampuan membaca gambar tersebut, sehingga panduan tersebut langsung dipasrahkan kepada tukang. Selain gambar kerja, tidak ditemukan panduan dengan format atau bahasa lain yang lebih mudah dipahami semua kalangan.

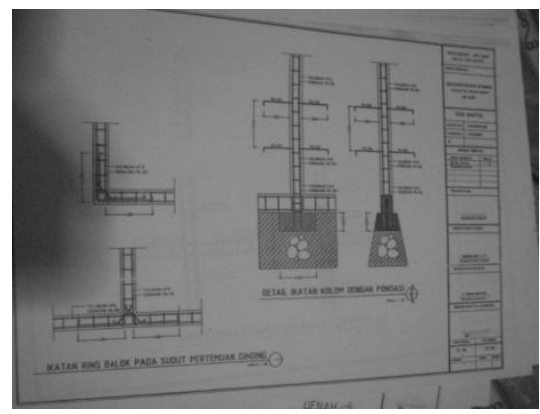

Gambar 8. Gambar panduan yang diterima pemilik rumah bantuan JRF

Ditemukan kondisi khusus pada tahap pra kontemplasi untuk rumah-rumah yang prosentase penerapan prinsip tahan gempanya cukup tinggi (diatas 60\%) ketika membangun mandiri. Pemilik rumah nomor 15, 9, dan 14 mendapat sosialisasi rumah tahan gempa secara rutin per minggu atau per bulan. Ada pula program pelatihan bagi pemilik dan tukang rumah nomor 8 .

\section{2) Tahap Kontemplasi}

Dari hasil penilaian fisik bangunan rumah, dapat dilihat bahwa pemilik rumah telah memutuskan untuk menerapkan prinsip tahan gempa saat menerima bantuan dari JRF. Karena adanya bantuan untuk meringankan cost, pemilik rumah merasa bahwa benefit memiliki rumah tahan gempa lebih besar daripada cost yang harus dikeluarkan saat membangunnya, seperti biaya yang besar, waktu membangun yang lama, dan teknis pembangunan yang lebih sulit.
Namun saat mengembangkan rumah dengan kemampuan sendiri, mereka merasa bahwa cost yang dikeluarkan lebih besar daripada benefit memiliki rumah tahan gempa. Ditambah lagi, tidak ada manfaat baru jika mereka membangun dengan prinsip tahan gempa. Juga tidak ada pengurangan benefit dan peningkatan cost pada alternatif membangun tanpa prinsip tahan gempa. Misalnya, belum ada sanksi nyata dari pemerintah apabila pemilik rumah membangun tanpa prinsip tahan gempa yang benar.

Disamping itu, tidak ditemukan usaha pelibatan pihak lain seperti keluarga dan tokoh masyarakat sebagai sumber informasi, sumber tekanan sosial, maupun sumber pujian untuk melakukan perilaku yang disosialisasikan. Keluarga maupun tokoh masyarakat belum bisa menekan atau mengedukasi pemilik rumah untuk terus membangun dengan prinsip tahan gempa. Tujuan dari tahap kontemplasi ini belum tercapai karena mayoritas pemilik rumah tidak memutuskan untuk melanjutkan penerapan prinsip tahan gempa.

\section{3) Tahap Aksi}

Dalam wawancara, pemilik rumah umumnya merasa mempunyai kemampuan untuk melaksanakan pembangunan dengan prinsip tahan gempa. Material atau jasa tukang yang diperlukan untuk membangun dengan prinsip tahan gempa juga telah tersedia di sekitar mereka. Tapi mereka menyalahkan lingkungan dan sistem sebagai alasan mereka tidak kembali membangun rumah tahan gempa, karena harga material yang dibutuhkan seperti besi dirasa mahal. Secara umum, tujuan dari tahap aksi belum tercapai karena pemilik rumah belum bisa mewujudkan pembangunan rumah tahan gempa kembali.

Pada tahap ini, kembali ditemukan catatan khusus untuk beberapa rumah yang penerapan prinsip tahan gempanya tinggi ketika membangun mandiri. Pada rumah nomor 9, 14, dan 15 pendampingan dan pengawasan saat menerima bantuan dahulu dilakukan intensif setiap hari oleh fasilitator. Pada rumah nomor 8 , 9 , dan 13 pemilik rumah ikut mengerjakan sendiri, bahkan pemilik rumah nomor 8 dan 13 menjadi ketua atau pengurus kelompok sehingga sering berinteraksi dengan fasilitator.

\section{(4) Tahap Pemeliharaan}

Program bantuan JRF telah memberikan materi yang dapat disimpan oleh pemilik rumah untuk mengingatkan mereka bahwa tindakannya membangun dengan prinsip tahan gempa sudah 
benar. Di muka rumah dipasang tanda pujian berupa plakat 'Rumah Tahan Gempa'.

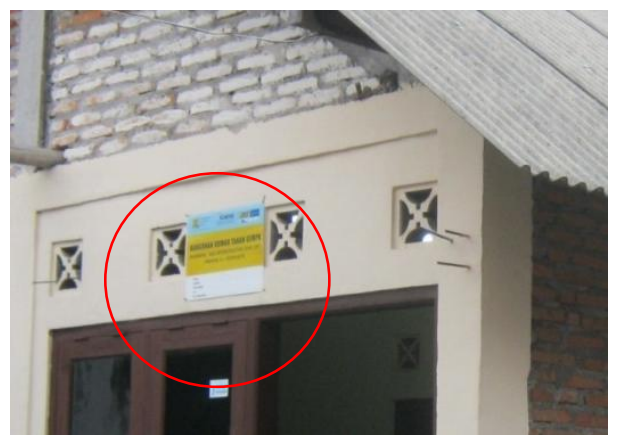

Gambar 9. Plakat Bangunan Tahan Gempa pada Rumah Bantuan JRF

Penghargaan lain yang diberikan berupa sertifikat rumah tahan gempa. Sertifikat ini sekaligus sebagai konfirmasi bahwa rumahnya memang telah terbukti tahan gempa tanpa perlu menunggu terjadi gempa lagi.

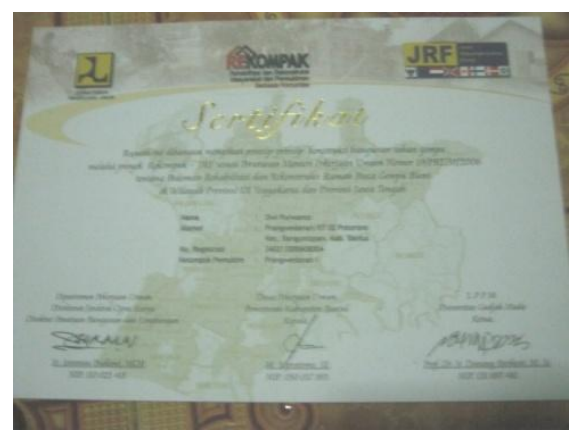

Gambar 10. Sertifikat Rumah Tahan Gempa Milik Penerima Bantuan JRF

Sayangnya, setelah program bantuan usai tidak ada lagi kegiatan lanjutan yang diadakan untuk mengingatkan pemilik rumah. Lingkungan juga kurang dikondisikan untuk meneruskan perilaku membangun tersebut, baik dengan pemasangan poster di tempat umum, atau melibatkan tokoh masyarakat untuk terus mengingatkan warga. Secara umum, tujuan tahap pemeliharaan belum tercapai, karena mayoritas penerima bantuan tidak melanjutkan penerapan prinsip tahan gempa.

\section{KESIMPULAN}

Dari penilaian terhadap fisik bangunan rumah tinggal, tingkat penerapan prinsip tahan gempa pada bagian rumah yang dibangun dengan program bantuan JRF sudah tinggi, namun pada bagian rumah yang dikembangkan secara mandiri oleh pemiliknya masih rendah.
Hal ini menunjukkan bahwa perubahan perilaku membangun yang diinginkan belum tercapai. Indikasi kegagalan perubahan perilaku terjadi di tahap kontemplasi, dimana pemilik rumah tidak memutuskan untuk melanjutkan penerapan prinsip tahan gempa yang pernah diajarkan.

Sistem bantuan tidak banyak berpengaruh terhadap kesadaran pemilik rumah, karena mereka sudah memiliki kesadaran atas pentingnya penerapan prinsip tahan gempa bahkan sebelum adanya edukasi oleh pemberi bantuan dalam tahap pra kontemplasi. Hanya saja mereka tidak memutuskan untuk membangun dengan prinsip tahan gempa saat membangun secara mandiri.

Sistem bantuan belum berhasil membuat tingkat penerapan prinsip tahan gempa tinggi saat pemilik rumah membangun sendiri, diduga karena tidak terpenuhinya beberapa prinsip pembelajaran adaptif yaitu:

1) Kegiatan sosialisasi hanya satu jenis.

2) Penyampaian panduan menggunakan gambar kerja dan penjelasan lisan yang mungkin sulit dipahami oleh semua orang, dibandingkan dengan praktik membangun langsung.

3) Pemilik rumah tidak banyak mengambil keputusan, dan tidak didorong untuk melakukan observasi mandiri dan personal reasoning.

4) Pemberi bantuan belum berhasil meyakinkan sebagian besar pemilik bahwa benefit memiliki rumah tahan gempa lebih besar daripada cost yang dibayar (biaya mahal, membangun lama, teknis sulit), terbukti dengan banyaknya pemilik rumah yang tidak meneruskan membangun dengan prinsip tahan gempa.

5) Kurangnya pelibatan pihak lain sebagai sumber informasi, tekanan, atau pujian.

6) Penentuan teknik konstruksi yang hanya satu jenis, tidak menyesuaikan kemampuan, kondisi ekonomi, dan kebiasaan masyarakat.

7) Tidak ada pendampingan teknis jangka panjang serta pengkondisian lingkungan untuk terus mengingatkan pemilik rumah mengenai manfaat rumah tahan gempa.

Meskipun demikian, ada beberapa poin pembelajaran adaptif yang sudah diterapkan dengan baik dalam program bantuan JRF yaitu adanya kegiatan sosialiasi prinsip tahan gempa, pengawasan oleh fasilitator, adanya pemberian reward, dan adanya pemberian dokumen pengingat untuk disimpan dalam jangka panjang 


\section{REFERENSI}

[1] Hadiwigeno, S. (2007). Mengawal Proses Rehabilitasi dan Rekonstruksi Pasca Gempa, Proceeding seminar Belajar dari Pengalaman Satu Tahun Gempa Bumi di Yogyakarta dan Jawa Tengah.

[2] APPL (2012). Peta Bantul. Dipetik digital 30 Juli 2012, Sumber: http://appl.or.id/wpcontent/uploads/2012/07/peta-bantul.png

[3] LP3Y (2007). Program Integratif Pemulihan Pasca Gempa di Bantul Jejaring FordFoundation. Dipetik digital 30 Juli 2012, Sumber: http://gis.lp3y.org/kecamatan/Banguntapan.p h

[4] Leersum, A. dan Arora, S. (2011). Implementing seismic resistant technologies in post-earthquake Pakistan : A process analysis of owner driven reconstruction, Habitat International 35, $254-264$

[5] Andreasen, Alan R. (1995). Marketing Social Change, Jossey-Bass Publisher, San Francisco, 141 - 169

[6] Boen, T. dan rekan (2006). Syarat-Syarat Minimum Bangunan Tembokan Bata/Batako Aman Gempa dengan Perkuatan Beton Bertulang Dinding Ampig Batu Bata. Jakarta: AustraliaIndonesia Facility for Disaster Reduction dan Badan Nasional Penanggulangan Bencana.
[7] Boen, T. dkk. (2009). Persyaratan Pokok Rumah yang Lebih Aman. Jakarta: Kementrian Pekerjaan Umum dan JICA.

[8] Boen, T. dan rekan (2010). Membangun Rumah Tembokan Tahan Gempa. Jakarta: Australia-Indonesia Facility for Disaster Reduction dan Badan Nasional Penanggulangan Bencana.

[9] Boen, T. dkk. (2010). Cara Memperbaiki Bangan Sederhana yang Rusak Akibat Gempa Bumi. Jakarta: Australia - Indonesia Facility for Disaster Reduction dan Badan Nasional Penanggulangan Bencana.

[10] Dirjen Cipta Karya (1993). Pedoman Pembangunan Bangunan Tahan Gempa. Jakarta: Departemen Pekerjaan Umum.

[11] Rini, J.A. (2012). Evaluasi Penerapan Prinsip Tahan Gempa pada Renovasi atau Rekonstruksi Rumah Pasca Gempa 2006 Di Yogyakarta. Tesis Magister. Institut Teknologi Bandung.

[12] Rini, J.A. (2014). The Application of Earthquake Resistant Principles in 2006 Earthquake Victim's Houses in Yogyakarta A Study on 18 APBN Fund Beneficiary Houses. Proceeding The $3^{\text {rd }}$ International Conference on Sustainable Built Environment (ICSBE) Resilience And Risk Reduction Towards Well-Being Society, $488-497$ 
